\title{
Poverty Incidence and its Determinants in the Estate Sector of Sri Lanka
}

\author{
Sinnathurai Vijayakumar, Brezinová Olga
}

\begin{abstract}
Poverty measurement and analysis are needed to identify the poor, the nature and extent of poverty and its determinants, and to assess the impact of policies and programmes on the poor. The government of Sri Lanka has been spending huge sums of money for poverty alleviation and social welfare since its independence. Yet, poverty is still severe and widespread in Sri Lanka, especially in the estate and rural areas. The objective of this study is to find out and analyze the significant determinants of the incidence of poverty in the estate sector where the highest level of chronic poverty and unemployment exist. The national and regional poverty survey data and other official socio economic cross sectional data from selected provinces were used to analyze the extent of poverty in plantation sector in which 89 Divisional Secretariat from provinces such as Subaragamuva, Central and Uva were considered for the analysis. The econometric model were fitted and estimated in this study. Furthermore, Log transformation was conducted and heteroskedasticity problem was detected with the use of statistical software. The Ordinary Least Square (OLS) regression analysis clearly indicates that, variables such as industrial employment, education, access to market and infrastructure significantly and negatively affect the poverty incidence of the estate sector. Also, agricultural employment has a negative impact but not significant. The R2 of 0.82 explains the statistical fitness of the model and the Prob (F-statistics) also confirms it. Analysis with the Durbin-Watson stat confirms that, there is no auto correlation between the variables. The results emphasize the need for adapting policies for regional infrastructural improvement as well as market and educational development in the plantation sector.
\end{abstract}

Key words: Chronic Poverty, Education, Infrastructural development, Poverty Incidence, Plantation sector.

\section{INTRODUCTION}

The reduction of incidence and severity of Poverty among the sectors has been the prime objective in their plan and budget preparation of most the developing countries across the world. Most of developing regions such as Asia, Africa, sub-Saharan are experiencing reduction of export earnings, increase in unemployment rate, and cut in international aid due to the recent economic crisis which has decreased world total output. 130 to 155 million people already pushed into poverty in 2008 due to soaring food and fuel prices. Particularly, decrease in GDP due to the economic crisis and natural disaster has had vast adverse effect on economies in the world. One percentage reduction in GDP growth could trap 20 million more people into poverty (Institute of policy studies of Colombo, 2009). What we can emphasize is that unstable growth, no doubt, will definitely have severe adverse impact on people who are already vulnerable. Therefore, government or policy makers should concentrate to the steady and stable GDP growth and at the same time they should confirm on trickling down of its benefits towards poor 
people because trickling down the growth's benefits toward poor people will definitely bring significant improvement in their social as well as economic conditions. As such, the incidence and severity of poverty will decrease to the considerable extent. There are three sectors in Sri Lanka such as urban, rural and estate. All areas administered by Municipal and Urban councils constitute the urban sector. Estate sector consists of all plantations which are 20 acres or more in extent and ten or more resident labourers. All areas other than urban and estate comprise the rural sector. Sri Lankan economy is basically rural in nature undergoing transition. Policy rigidities are coupled with economic problems in widening the gap between Urban, rural and estate sector (Plantation sector). Generally large majority of the people in a country live in rural areas. The depth and severity of poverty are also the highest among estate sector in Sri Lanka. Individuals living in estate and rural communities experience a variety of economic and social constraints, including short falls in access to productive assets like land and water, gap in physical infrastructures like power, transport and communications, imperfectly functioning product and input markets, inadequate technology and weak institutional arrangements. Generally, through poverty estimation, we can find out level of poverty of a country and its causes, especially in various sectors in Sri Lanka. The people of estate sector are undergoing very low level of living and severe poverty ridden condition. They are people who play crucial role in contributing to the foreign exchange earnings from total export. Because till today Sri Lankan economy depends upon estate sector to earn foreign exchange from primary commodities such as tea rubber and coconut which are produced by estate sector.

\section{THEORETICAL BACKROUND AND LITERATURE REVIEW}

As already mentioned, poverty is the major problem and great challenges faced by all developing countries (World Bank, 2001). This is not different in case of Sri Lanka. Large number of poverty alleviation programmes has been implemented by successive Sri Lankan government since independence. But majority of rural and estate people are yet under severe poverty ridden conditions. Poverty assessment focuses not only on the lack of material deprivation but also on the deprivation of non-tangible services such as education, health and shelter (Semasinghe, 2009). There is no general consensus on any meaningful definition of poverty in the literature. In past, poverty was viewed primarily as a problem of economic insufficiency, but its meaning has now been broadened to encompass material deprivation, human deprivation, including low achievements in education and health, vulnerability, voiceless, powerlessness and exposure to risk. Thus, in attempting to solve the problem of poverty in its totality, one has to consider not only economic dimension but also the social, cultural and political dimension. Poverty in Sri Lanka is basically rural phenomenon (Dileni, 2004). In consonance with several literature of poverty, poverty has five dimensions of deprivation namely: personal and physical deprivation, economic deprivation, social deprivation, cultural deprivation, and political deprivation. Personal and physical deprivation can be experienced in nutritional, educational, health and literacy deficiency and lack of self confidence. Economic deprivation includes lack of access to property, income, assets, finance and factors of production. Social deprivation is manifested in impediments to full participation in social, political and economic life. Cultural deprivation is when people are deprived in terms of values, beliefs, attitudes, knowledge, orientation 
and information. Based on this, they are not able to take advantage of economic and political opportunities. Ignorance, among other things, undermines access to legal institutions. The poor lack political voice. Thus, people of estate sector are highly ignored by politicians. Not only that estate sector has higher average house hold size compared to other sectors and this is also considered a cause for poor living conditions within community (Samaraweera, 2009). At regional and village levels of estate sector, poverty and inequality have been associated with variety of economic, social and political reasons in Sri Lanka (Palitha \& Nimal, 2006).

There are two types of poverty such as absolute and relative poverty. Absolute poverty is lack of adequate resources to obtain and consume a certain bundle of goods and services. Such a bundle of goods and services would contain an objective minimum of basic necessities such as food, shelter and clothing. There are two major problems associated with this definition. The first is what we include in the objective minimum and the second is how we set minimum standards for basic necessities like clothing, food, transportation etc. which often depend on individual taste, cultural norms and values, and the prevailing socio-economic conditions within a given society or nation .Thus, absolute poverty is characterized by low calorie intake, poor housing conditions, inadequate health facilities, poor quality of educational facilities, low life expectancy, high infant mortality, low income, unemployment and under employment. An alternative approach is to define poverty as being relative poverty with respect to the living standards that prevail in a given society or nation. A major advantage of this approach is that it reflects the changing perceptions of acceptable minimum living standards. The relative poverty is a measure of income inequality. Usually, relative poverty is measured as the percentage of population with income less than some fixed proportion of median income. There are several other different income inequality metrics, for example the Gini coefficient. Several researchers have opted for relative definition of poverty. Many economists have stated that both absolute and relative poverty are closely aligned to inequality in income distribution. The poverty as a concept is closely related to inequality given the average income level and a higher level of inequalities will be associated with high level of poverty (Sen, 1984). It is real fact that the poverty reduction will depend on the rate of average income growth, the initial level of inequality, and changes in the level of inequality (World Bank, 2001). The majority of studies seems to suggest that high initial inequality is harmful for overall economic growth, and thus for poverty reduction, at least in environments of very high (income or asset) inequality (World Bank, 2001; Chen and Ravallion, 2001). Therefore, what is understood from the fact is that employment generation via growth of industrial and agricultural development, infrastructural development, poverty reduction and income inequality are interrelated to each other. Poverty can be made between temporary and chronic poverty. The transient poverty otherwise known as poverty of the hopeful is temporary. It may arise from theft, drought, war, flood and fire. The unemployed as a result of economic recession fall into this group. Chronic poverty, on the other hand is long term and persistent. Its causes are largely structural. Chronic poverty may be so as to describe the average life in a society. Even though estate poor provide high contributions to the economic growth of Sri Lanka in terms of production and export earnings, they are still politically as well as physically deprived in Sri Lanka. Access to market and road facilities in estate sector lagged far behind the urban sector. The social and economic infrastructural facilities like roads, access to market, education, and health are precondition for economic 
growth, employment generation and poverty reduction. Opportunities for getting employment from industry are very difficult for estate people in Sri Lanka. Conversely, they mainly depend on agriculture for employment opportunities. It is the important fact that people of estate sector are undergoing very poor social and economic infrastructural facilities for long period. Poverty of estate sector in Sri Lanka is associated with poor infrastructure (Dileni, 2004; De Silva, 2009). Therefore, agricultural and industrial employments have been considered in the present study with variables such as education, roads and access to market. Much qualitative and very few econometric studies with regard to poverty of estate sector has been done in Sri Lankan context. All factors like education, roads, access to market, industrial and agricultural employment has not been taken together in the econometric studies of estate poverty so far. Therefore the present study focuses on above said variables simultaneously for the analysis.

\section{OBJECTIVES OF STUDIES}

As already explicated, estate poor lack political voice. Regional politicians are not interested to improve the infrastructural facilities which are precondition for the development of the region and thereby reducing poverty. Therefore, incidence and severity of poverty is highest in estate sector than other sectors in Sri Lanka. The majority of the poor in the estate sector are clustered below the poverty line and non poor in estate sector is also almost clustered around the poverty line. Thus, they are highly vulnerable to the policy making of government as well as any economic social and natural shock such as flood, draught etc. Therefore, main objective of the study is to find out and examine the prime determinants of poverty incidence of plantation sector with the help of econometric method and suggesting proper remedial measures for this issue to the policy makers.

\section{METHODOLOGY}

This study is fully based on secondary data drawn from House hold Income and Expenditure survey by Department of Census and Statistics (DCS). The study mainly pays to the attention to the places such as Subragamuva, Central and Uva provinces where most of estate sectors have concentrated. Therefore, 89 Divisional Secretariat Divisions (DSD) have been taken into account to find out the significance of determinants of poverty incidence from above stated provinces. Even though Poverty status of Sri Lanka has been analyzed by some researchers, there is lack of econometric analysis (Dhanapala, 2005), particularly in the poverty incidence of plantation sector. The multiple regression model is used on cross sectional data to find out determinants of poverty incidence and its significance and log transformation has been done. Heteroskedasticity problem has been detected by using Eviews option. In this study, several variables have been considered like market availability, roads, education, industrial employment, agricultural employment The coefficient of those variables refer to elasticity of concerned variables. The entire analysis has been carried out with the use of econometric concepts of simple linear regression model. 


\section{POVERTY IN SRI LANKA}

Sri Lanka's human development index is by far the highest in South Asia and exceeds that of the rich countries. This level of human development has been achieved through the provision of universal access to health, education and continued investment in the social sectors. Economic development however has lagged consistently behind the social development (Vijayakumar, 2010). The fact remains that although the outlay of the government on health and education has remarkably improved the human development index yet, it has not gone long way in reducing poverty level. Sri Lanka is on the track to achieve Millennium Development Goal (MDG) of most of the health and education indicators. But, improvements in the MDG indicators to equity in education and health do not show similar improvements. Table 1 shows that the head count index for Sri Lanka-percentage of population below the poverty line- has decreased from 26.2 percent in 1990/91 to 15.2 percent in 2006 /07. Further, there is clear fact that incidence of poverty in urban has remarkably decreased and in estate sector it has increased in considerable size. The incidence of poverty in urban sector is 16.3\% in 1990/91 and $14 \%, 7.9,6.7 \%$ in $1995 / 96,2002,2006 / 07$ respectively. What is observable here is that there is continuous and significant reduction in the urban poverty that already passing expected MDGs target of 8.1percentage. Rural sector also has similar pattern in regard to poverty incidence but not significant.

Tab. 1 - Poverty Trends in Sri Lanka. Source: Department of Census and Statistics, Household Income and Expenditure Survey.

\begin{tabular}{|c|c|c|c|c|}
\hline & $1990 / 91$ & $1995 / 96$ & 2002 & $2006 / 07$ \\
\hline \multicolumn{5}{|c|}{ Poverty Head Count Index (PHC) } \\
\hline Sri Lanka & 26.1 & 28.8 & 22.7 & 15.2 \\
\hline Urban & 16.3 & 14.4 & 7.9 & 6.2 \\
\hline Rural & 29.4 & 30.4 & 24.7 & 15.2 \\
\hline Estate & 20.5 & 38.4 & 30.0 & 30.2 \\
\hline \multicolumn{5}{|c|}{ Poverty Gap Index (PGI) } \\
\hline Sri Lanka & 5.6 & 6.6 & 5.1 & 3.1 \\
\hline Urban & 3.7 & 7.2 & 1.7 & 1.3 \\
\hline Rural & 6.3 & 7.2 & 5.6 & 1.2 \\
\hline Estate & 3.3 & 7.9 & 6.0 & 6.2 \\
\hline \multicolumn{5}{|c|}{ Square Poverty Gap Index (SPGI) } \\
\hline Sri Lanka & 1.8 & 2.2 & 1.6 & 0.9 \\
\hline Urban & 1.3 & 0.9 & 0.5 & 0.4 \\
\hline Rural & 2.0 & 2.5 & 1.8 & 1.0 \\
\hline Eatate & 0.9 & 2.5 & 1.8 & 1.8 \\
\hline
\end{tabular}

Table 1, further shows that the incidence of poverty in estate sector, accounting for around one million people in total population, has increased from $20.5 \%$ in 1990/91 to $38.4 \%$ in 1995/96.Despite an improvement thereafter with marginal decline in head count ratio to $30 \%$ 
in 2002. But, poverty head count index in estate sector has increased to $32 \%$ in 2006/07 while other two sectors like urban and rural sector experienced a decline. Poverty Gap Index (PGI) in urban sector has also significantly declined from 3.7 in 1990/91 to 1.3 in 2006/07. In rural sector, PGI declined from 6.3 in 1990/91 to 3.2 in 2006/07. In the estate sector, it has increased from 3.3 in 1990/91 to 6.2 in 2006/07. It is noted that there is reduction in poverty gap index nearly by two third in urban sector and during the same period, in estate sector the poverty gap index has increased by two fold. Further, Square poverty gap index (SPGI) has also increased in estate sector from 0.9 to 1.8 during the same period, indicating vast increase in severity of poverty in the estate sector between 1990/91 to 2006/07. Further, Gini co-efficient (table 2) has also proved the inequality of income distribution and severity of estate sector poverty. Table 2 clearly explains the poverty and income inequality of various sectors in Sri Lanka. As mentioned above, the urban sector reported the lowest SPGI but highest Gini co-efficient among the sectors. The SPGI measures inequality among the poor, while the Gini co-efficient measures overall inequality, when both poor and non-poor are considered together. According to the SPGI, inequality among the poor is low in urban sector even though Gini co-efficient is the highest indicating that overall inequality is higher in urban sector than estate sector. But, the situation in the estate sector is exactly opposite, except in 1990/91. Gini co-efficient in estate sector is the lowest indicating that even the non- poor are also not much far above poverty line .Most of estate non-poor are clustered just above poverty line. As such, they could slip easily into poverty if there is unfavorable policy making as well as any economic crisis or severe inflation. The SPGI in estate sector indicates that inequality among the poor who is below poverty line is the highest.

Tab. 2 - Gini co-efficient of Per Capita Expenditure. Source: Department of Census and Statistics, Household Income and Expenditure Survey.

\begin{tabular}{|l|c|c|c|c|}
\hline & $1990 / 91$ & $1995 / 96$ & 2000 & $2006 / 07$ \\
\hline Sri Lanka & 0.32 & 0.35 & 0.4 & 0.41 \\
\hline Urban & 0.37 & 0.38 & 0.42 & 0.46 \\
\hline Rural & 0.29 & 0.33 & 0.39 & 0.39 \\
\hline Estate & 0.22 & 0.20 & 0.26 & 0.23 \\
\hline
\end{tabular}

What is understandable from above stated fact is that compared to urban sector where dynamic and manufacturing industries are concentrated, estate people are under severe poverty ridden condition and vulnerable due to the any economic shocks. The World Bank report states that poverty reduction in Sri Lanka has been uneven across sectors-rapid in the urban sector, but slow or stagnant in rural and estate sectors. While urban poverty halved during this period, rural poverty declined by less than five percentage points and poverty in the estates (plantation sector) increased significantly_ making this sector the poorest in the country. The higher poverty among estate households is associated with the remoteness or lack of useable year-round roads linking the estate to the nearest town (World Bank, 2005). In brief, it is the fact that all poverty indicators such as PHC, PGI, SPGI, Gini co-efficient show that majority of the poor in the estate sector are clustered around the poverty line and therefore, are highly vulnerable to unfavorable policy making as well as any economic and natural shock such as 
flood, draught .Estate sector (plantation sector) is place where the highest levels of extreme poverty, inequality and unemployment are focalized in many countries like Sri Lanka. Beckford (1972) recognizes that poverty and income inequality distribution in plantation sector are a global phenomenon. Even today's advanced economies experience socio economic issues related to poverty and income inequality in the estate sector as found in the sugarcane plantation in Louisiana (Parke, 2003) and Georgia's cotton plantation belt in the United States (Levernier \& white, 1998). Levernier and White(1998) state that while economic demographic and human capital characteristics of an area affect the area's poverty rate, an additional impact is expected by institutionalized cultural characteristics of a certain social group over that area's regular economic demographic and human capital characteristics that would make it qualified for having a relatively low or relatively high poverty rate. As depicted above, severe or chronic poverty is not exceptional case in the plantation sector of Sri Lanka. Sri Lanka, western province play crucial role in contributing to the national GDP Because it is a place where most of manufacturing sectors and infrastructural facilities has concentrated.Thus incidence of poverty is the lowest and average the income is highest in western province. Thereby, there are vast regional disparities due to sluggish agricultural growth and related activities, regional disparities in infrastructural facilities.

\section{MODEL SPECIFICATIONS}

As already mentioned above, this study focuses on poverty incidence among the sectors and determinants of poverty incidence in estate sector. The researcher indicates the fact that incidence of poverty is determined by five variables, namely Roads, education, access to market, industrial employment and Agricultural employment. Therefore, researcher uses the following model which has been used by some researchers analyzing the same issue in other some countries. The basic model is, thus illustrated below in which the poverty incidence is function of several related variables.

$\mathrm{HI}=f($ AGREMP, EDU, INDEMP, , MAR, ROD)

On the basis of this function, multiple regression models can be written as follows

$\mathrm{HI}=\beta_{\mathrm{O}}+\beta_{1} \mathrm{AGR}+\beta_{2} \mathrm{EDU}+\beta_{3} \mathrm{IND}+\beta_{4} \mathrm{MAR}+\beta_{5} \mathrm{ROD}$

In equation, HI is incidence of poverty in a Divisional Secretariat Division as calculated by DCS based on national poverty line and others such as ROD ,EDU,INDEMP,AGREMP,MAR refer to roads, education, industrial employment, agricultural employment, access to market respectively. The ut is error term. Human capital development is given by education in which it is expected that there is negative relationship between education and incidence of poverty. The access to market which increases income generation of people, food availability and food access have positive impact in poverty reduction (Woldemariam \& Mahammed 2003) Thus, it is expected to be negative relationship between access to market and poverty incidence. Increasing industrial output and employment of region is positively correlated with increased income and negatively correlated poverty incidence (Dungam \& Kelegama, 1997; Shaw, 1999) .Thus, industrial employment (INDEMP) in DSD level which is expected to be negative impact on 
poverty incidence serve as proxy for overall industrialization because value addition to primary commodities through industrial activities helps to generate employment and better income opportunities. The level of infrastructural development decreases with distance of the nearest town of any town and will considerably help to obtain income opportunities. Therefore, Road is considered as proxy variable for overall infrastructure .It is expected to have negative relationship with poverty incidence. The agricultural employment is expected to be negative relationship with poverty incidence in estate sector because most of estate people are getting wage from plantation such as tea, rubber and coconut, etc .If production increases, wage labourers can get employment opportunity and wage increase which confirm cost of their basic needs .(Most of them are wage labourers in estate sector). The equation one can be rearranged in $\log$ form for our purpose of study as follows

$$
\text { InHI }=\beta_{\mathrm{O}}+\beta_{1} \text { InAGR }+\beta_{2} \operatorname{InEDU}+\beta_{3} \operatorname{InIND}+\beta_{4} \operatorname{InMAR}+\beta_{5} \operatorname{InROD}
$$

Gunatilaka and Ghotikapanich (2005) used almost similar regression model to analyze inequality trends and determinants in Sri Lanka during the period of 1980 -2002. Accordingly, the current approach is to identify and examine the main determinants and significance associated with DCS of estate sectors as a simple model with several variables that explains incidence of poverty. The results of the OLS are summarized in the following equation and table 3.

$\mathrm{HI}=4.92963-0.05732 \mathrm{InAGR}-0.025102 \mathrm{InEDU}-0.050398 \mathrm{InIND}-0.150869$ InMAR-0.1997591InROD

$$
\mathrm{t}=(28.81184)(-1.481582) \quad(-3.2484831) \quad(-2.079317)
$$

\section{EMPIRICAL RESULTS AND DISCUSSION}

Cross sectional data for 2006-07 time periods are used for estimation using Eviews software. The summarized results of regression are shown in table 3 . The value of R2 of 0.821 means that about 82 percent of the variation in poverty incidence of plantation sector is explained by above mentioned five variables such as agricultural employment (AGRE), education (EDU) ,industrial employment (IND), access to market( MAR), road facilities (ROD). In other words, high R2 (0.82) indicates the statistical fitness of the model used to analyze the determinants of poverty incidence in plantation sector. In addition to R2, prob (F-statistics) also confirms the statistical fitness of the model. In accordance with regression result of table 3 , as already predicted ,all explanatory variables has negative sign indicating the negative relationship between poverty incidence and explanatory variables. 
Tab. 3 - Ordinary Least Square Regression results. Source: Author's own

\begin{tabular}{|l|c|c|c|c|}
\hline \multicolumn{1}{|c|}{ Variable } & Coefficient & Std. Error & t-Statistic & Prob. \\
\hline LEDU & -0.025102 & 0.007727 & -3.248481 & 0.0017 \\
\hline LIND & -0.050398 & 0.024238 & -2.079317 & 0.0408 \\
\hline LMAR & -0.150869 & 0.044561 & -3.385663 & 0.0011 \\
\hline LROD & -0.199759 & 0.046948 & -4.254903 & \\
\hline 0.0001 & & & & \\
\hline LAGRE & 0.507312 & 0.038683 & 1.481582 & 0.1423 \\
\hline LAGRE & -0.057312 & 0.038683 & -1.481582 & 0.1423 \\
\hline C & & & & \\
\hline C & -4.929630 & 0.171097 & 28.81184 & 0.0000 \\
\hline R-squared & 0.821352 & Mean dependent var & 3.333995 & \\
\hline Adjusted R-squared & 0.810325 & S.D. dependent var & 0.259947 & \\
\hline S.E. of regression & 0.113211 & Akaike info criterion & -1.452652 & \\
\hline Sum squared resid & 1.038158 & Schwarz criterion & -1.282589 & \\
\hline Log likelihood & 69.19036 & F-statistic & 74.48135 & \\
\hline Durbin-Watson stat & 1.649029 & Prob(F-statistic) & 0.000000 & \\
\hline A & & & \\
\hline
\end{tabular}

According to the table 3 , the co-efficient of agricultural employment has negative relationships with incidence of poverty. When education, industrial employment, access to market and roads remain constant, a $1 \%$ rise in agricultural employment decreases $\mathrm{HI}$ by $0.05 \%$. But, its p-value is greater than 0.05 indicating that there is insignificant impact of agriculture employment on poverty incidence. Dhanapala (2006) in his studies also mentioned that agriculture sector does not significantly contribute to the poverty reduction. This result is entirely true because most of the people are getting very low wage from plantation companies that is not adequate to fulfill their basic needs and children's education. Further, their wage earnings also depend upon changes in natural climate as well as international price and demand fluctuation of tea rubber and coconut. Most of the estate people highly depend on agriculture like tea, rubber, and coconut for their livelihood income and most of them are wage labourers. Besides, wages can be increased by bargaining of Employees' trade union which is under control of regional politicians. Generally, politicians are always reluctant to push up wages via making effort for negotiation with plantation companies and employers. As a result, poverty is transmitted to next generations in estate sector. However, agriculture, which is expected to reduce the poverty, does not seem to be effective according to the results. As other factors remain constant, a $1 \%$ increases in education decreases the poverty incidence by $0.25 \%$ and vice versa. Its p-value is 0.001 that indicates the significance of education. The p-value (0.04) of industrial employment which is less than 0.05 shows the significance of that variable. As variable of industrial employment increases incidence of poverty has decreased as already predicted. Further, the regression results suggest that access to market has a negative relationship with incidence of poverty as already predicted. When other variables like agricultural employment, education, industrial employment, roads remain constant, a 1\% increase in MAR (access to market) will make poverty in- 
cidence to decrease by 0.15 and its p-value which tells us the significance of variable (InMAR) is 0.01 . Likewise, other factors remain constant, a $1 \%$ increase in road facilities will decline the incidence of poverty around by $0.2 \%$ and variable ROD is more significant because its p-value (0.0001) is less than 0.05. Durbin-Watson value confirms that there is no autocorrelation and further, in addition to R2, prob (F-statistics) also confirms the statistical fitness of the model. Even though estate poor provide high contributions to the economic growth of Sri Lanka in terms of production of tea, rubber and export earnings, they are still undergoing chronic poverty in a country. Average wage is not enough to fulfill their basic needs and children's education (Gunatilaka, 2003). Therefore, there is high drop out from schools and thereby school children engage in earnings activities for very low wage. What is observable fact is that average earners in family are high but average family income is low in estate sector compared to urban sector in Sri Lanka. Persistent poverty is impediment to parents to provide better education to their children. The drop out from school or lack of adequate education leads to low wage. But, it is the fact that the estate people who have good education are undergoing better living standard and they are easily able to find out the job from industry or other sources in which they confirm themselves their livelihood. However, another ground for poverty in estate sector is poor and inadequate infrastructural facilities. Poverty of estate sector in Sri Lanka is associated with poor infrastructure (Dileni, 2004). Lack of adequate roads and access to market is impediment for the generation of employment, low level cost of living and average health and education. In fact, politicians are responsible for the allocation of resources to develop social and economic infrastructural facilities in the region. But, they are not interested in developing these facilities. What Regional politicians think is that people should not have awareness about politics for the sake of their persistent political survival. Therefore, poverty is transmitted to next generations in estate sector in Sri Lanka. Ogwumike(1995) also mentioned in his studies of poverty alleviation strategies of Nigeria that chronic poverty may be transmitted from one generation to another and it is very persistent.

\section{CONCLUSIONS AND SUGGESTIONS}

The paper has analyzed the incidence and severity of poverty among the sectors and main determinants of poverty incidence in Plantation sector with the help of cross sectional data. In brief, the result brings to light the fact that the Variables such as MAR , ROD, EDU, IND, has significantly negative influence on the incidence of poverty in estate sector of Sri Lanka . Particularly, ROD,MAR and EDU have significant impact on incidence of poverty emphasizing the needs for vast improvement in infrastructure and education in estate sector. Further, R2 of 0.82 and p-value (F-statistics) clearly show the fitness of the model used in this studies. Although halving poverty by 2015 is a great challenge, Sri Lanka has good opportunities, as per findings of the study, to reduce the poverty through taking appropriate remedial measures with present supportive human development. The estate sector is found to be lack of road facilities and poor condition of existing roads which causes the long distance between urban and estate sector and also within the estate sectors. As such, access to market is also significantly poor in nature. Compared to urban sector, they are undergoing poor and low level education and as a result, there is a severe shortage for technical and skilled human resources. As a result, most 
of estate people are wage labourers. Thus, strengthening the human capabilities at grass root level or village level via good education will enhance the ability of poor people to earn money and to plan their expenditure and to save the money for unexpected and future needs. Thus, the study emphasizes the fact that government should concentrate the development of infrastructural facilities as well as education in grass root level which will considerably decrease the incidence and severity of poverty. Increasing small and medium industrial development will also increase the employment opportunities and confirm the earning of the stable income with the help of micro finance and other government inducement and support.

\section{References}

1. Beckford, G. L. (1972). Persistent of poverty: Unemployment in plantation economies of the Third world. University press of the West Indies.

2. Dhanapala, T.R.W. (2007). Determinants of the regional poverty incidence in Sri Lanka and the impact of the estate sector population. Annual research journal of SLSAJ, 6, 95-101.

3. De Silva, I. (2009). Micro level determinants of poverty reduction in Sri Lanka: Multivariate approach. International Journal of Social Economics, 35(3), 140-158. http://dx.doi.org/10.1108/03 068290810847833

4. Dileni, G. (2004). Poverty measurement: meanings, methods and requirements. Colombo: Centre for Poverty Analysis.

5. Dunham, D. \& Kelegama, S. (1997). Stabilization and adjustment: A second look at the Sri Lankan experience-1977-1993. The Developing Economies, 35(2), 207-219. http://dx.doi. org/10.1111/j.1746-1049.1997.tb01191.x

6. Chen, S. \& Ravallion, M. (2001). How did the World's poorest fare in 1990s? Review of Income and Wealth, 47 (3), 283-300. http://dx.doi.org/10.1111/1475-4991.00018

7. Central Bank of Sri Lanka. Annual reports (2005-2008). Colombo.

8. Department of Census and Statistics. Various reports 2000-2009. Colombo.

9. Gunatilaka, R. \& Chotikspanich, D. (2006). Inequality trends and determinants in Sri Lanka 19802002: A shapely approach to decomposition. Australia: Department of Econometrics and Business statistics, Moans University.

10. Gunatilaka, R. (2003). Wage trends and labour market integration in Sri Lanka's central province. Srilanka Economic Journal, 4(2), 81-104.

11. Institute of Policy Studies of Sri Lanka, Annual report 2009.

12. Levernier, W. \& White, J. (1998). The determinants of poverty in Georgia's plantation belt, explaining the differences in measured poverty rates. The American Journal of Economics and Sociology, 57(1), 47-70. http://dx.doi.org/10.1111/j.1536-7150.1998.tb03257.x

13. Nimal, A. \& Palitha, E. (2006). Challenges of poverty and inequality : Public priority action on infrastructure services in Sri Lanka. In P. Thalayasingam and K. Arunasalam (Eds.), Does inequality matter? Exploring the links between poverty and inequality (pp. 81-125). Colombo: Centre for Poverty Analysis. 
14. Oguwumike, F.O. (1998). Poverty alleviation strategies in Nigeria: Measuring and monitoring poverty in Nigeria. Proceeding of the seventh Annual conference of zonal Research Unites of Central Bank of Nigeria.

15. Samaraweera, G,R. (2009). The relationship between poverty and population characteristics in the Estate sector of Sri Lanka. Sri Lanka Journal of Humanities and Social Sciences, 1 (1), 31 45.

16. Semasinghe, W.M. (2009). Dimensions of rural Poverty in Sri Lanka: An attempt to identify the crucial aspects of well-being of rural poor. Sri Lanka Journal of Humanities and Social Sciences, 1(1), 16-30.

17. Sen, A. K. (1983). Poverty and Famines. London: Oxford University Press. http://dx.doi.org/1 0.1093/0198284632.001.0001

18. Shan, D. (1988). The effects of price and income changes on food energy intake in Sri Lanka. Economic Development and Cultural change, 36 (2), 315-340. http://dx.doi.org/10.1086/451654

19. Shaw, J. (1999). A World Bank intervention in the Sri Lankan welfare sector: the national development trust fund. World Development, 27(5), 825-838. http://dx.doi.org/10.1016/S0305750X(99)00028-5

20. Vijayakumar, S. (2010). Poverty Status and impact of poverty alleviation policies in Sri Lanka: Special reference to samurdhi, education and health. Proceedings of Annual International Research Conference of Annamalai University (pp. 24-31), India.

21. Woldemariam E. \& Mohammed, L. (2003). Poverty Mapping for selected African Countries, United Nations' Economic Commission for Africa.

22. World Bank. (2005). Attaining the millennium development goals in Sri Lanka, How likely and What will it take to reduce Poverty, Child Mortality and Malnutrition, and to increase School Enrolment and competition? (World Bank Report, No32143LK), South Asia Region, Washinton,D.C.

23. World Bank. (2001). World development report2000/2001. New York: Oxford University Press.

\section{Contact information}

Sinnathurai Vijayakumar, B.A.(Hons)., M.A., M.Phil

Faculty of Economics and Management, Tomas Bata University in Zlin

Mostni 5139, Zlin, Crech Republic

Department of Economics, University of Jaffna, Sri Lanka

E-mail:vijai114@gmail.com

doc. PhDr. Olga Brezinová, CSc.

Faculty of Economics and Management,Tomas Bata University in Zlin

Mostni 5139, Zlin, Czech Republic

E-mail:brezinova@fame.utb.c\%.

JEL Classification: I32, I38 